\title{
Status of Women Education in India
}

\author{
Deepmala Yadav \\ Research Scholar, Bangalore University, Bengaluru, Karnataka, India \\ https://orcid.org/0000-0003-0863-9397
}

\section{OPEN ACCESS}

Manuscript ID:

ECO-2020-09013451

Volume: 9

Issue: 1

Month: December

Year: 2020

P-ISSN: 2319-961X

E-ISSN: 2582-0192

Received: 23.09.2020

Accepted: 20.10 .2020

Published: 01.12.2020

Citation:

Yadav, Deepmala, and Suma Singh. "Status of Women Education in India." Shanlax International Journal of Economics, vol. 9, no. 1, 2020, pp. 28-35.

DOI:

https://doi.org/10.34293/ economics.v9i1.3451

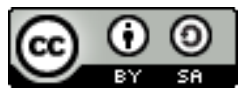

This work is licensed under a Creative Commons Attribution-ShareAlike 4.0 International License

\author{
Suma Singh \\ Associate Professor, Mount Carmel College, Bengaluru, Karnataka, India
}

\begin{abstract}
Women in India, despite being half of the population, do not represent themselves in educationrelated indicators with the same magnitude. Prima facie, it can be said that we achieved 100 percent enrolment and gained 1.01 in the gender parity index at the primary level. However, when in-depth analysis is done considering the quality aspects and women's participation in the labor force, we will find gender biases at all levels. The girls' enrolment is significantly low as compared to their male counterparts in private schools, in high-end technological and management institute, and professional courses. In addition to that, girls are lagging in cognitive skills, Maths, and reading abilities. In a nutshell, girls are still struggling to be on par with their male counterparts to get quality and professional education. Parental behavior, intra-household resource allocation, cultural norms, safety, discrimination at the workplace can be attributed to these discrepancies. The present paper will analyze the status of women in educational development, factors, and determinants associated with disparity, and government policies for upliftment of women's situation in education.
\end{abstract}

Keywords: Status of women' education at a different level, Enrollment in private schools, Dropouts, Gender disparity, Geographical variation.

\section{Introduction}

Smart Economies is built on the foundation of Gender equality as women getting equal access to social, economic, and political opportunities is critical for sustained economic development. Economic history reveals that the empowering of women begins with access to Education. Several initiatives have been taken at the global and national levels to ensure women have equal access to education at all levels.

Education For All (EFA) is a global movement led by UNESCO (United Nations Educational, Scientific and Cultural Organization), aiming to meet the learning needs of all children, youth, and adults. Indian constitution provides for free and compulsory education. Through major public policy initiatives such as Sarva Shiksha Abhiyan (Education for All), the Government of India has tried to attain universalization of elementary education, which would also achieve a reduction of gender disparity. Government intervention has achieved gender parity at the primary level and increased enrollment at secondary and tertiary levels. However, if enrollment in private schools, top management, and technical colleges are taken into account, then data reveals that girls are still lagging, and they have a long way to go to be on par with their male counterparts. The share of female students is lowest in Institutions of National Importance followed by Private Open Universities, Deemed Universities, and State University (AISHE, 2018-19).

The gender disparity in terms of access to education and, in particular, higher education can be attributed to multiple factors at the macro and micro levels. The societal and cultural norms shape parents' perception of prioritizing 
male child education over the female child. This has prevented the entry of women into the labor market and, more important, deprived them of lucrative jobs and leadership roles. Denying the $50 \%$ of the population access to higher education and the job market hurts economic growth.

\section{Review of Literature}

There has always been a gap in male and female literacy rates; however, the gap varies in different regions and groups. Discrepancies can be observed at different levels of education. They are higher at the secondary level than that of the primary level (Tilak, 1996).

Children belong to Scheduled castes, and Scheduled tribes (SC/ST) and Other Backward Castes (OBC) are less likely to go to school than children belonging to General Category. The educational disadvantage is more for girls in these categories (Drez and Kingdon, 2003).

This discrimination may be either through choosing not to enroll girls in the school or through lower expenditures on her schooling (Choudhary and Roy, 2006). Parents don't want to spend much on a girls' education due to the prevailing social and cultural norms (Mohanty, 2006).

Poor retention and lower completion rates at the primary level persisted, and the problem was more intense for SC and ST girls (Govinda R. and Madhumita Bandhopadhyay, 2008).

Various factors influence a girl's education. Families in which mothers are educated spent more on girl's education (Kambhapati, 2008). Parents prefer to educate their sons because they provide financial support in their old age and are heirs of the property (Bose, 2012). Due to this tendency, girls from poorer households, lower socio-economic backgrounds, from rural areas are less likely to attend private schools (Harma, 2011; Maitra et al., 2013) because private schools are perceived to be better in quality by parents and are fee-charging (expensive as compared to government schools) (De; Noronha; C. Samson, M.; 2003).

Government policies have brought major improvement. Except for Rajasthan, Bihar, Orissa, and Jharkhand, more than 95 percent of the girls are enrolled across India. Certain programs and strategies have improved the quality of and access to education. However, some children enrolled in the school are at the risk of dropping out. The gross enrollment ratio of women in higher education is continuously increasing, but they are lagging in engineering, medical and management faculty (Lal, K. and Arora, V.2016).

\section{Methodology}

The present work is based on secondary data from various government reports and literature. The gender-based analysis is done by utilizing the data about enrollment at different levels. Data has been taken from National Statistical Organization, Ministry of Statistics and Programme Implementation, Unified District Information System for Education (U-DISE), University Grant Commission Annual Report, All India Survey for Higher Education (AISHE), Ministry of Human and Resource Development (MHRD) for the study.

\section{Objectives}

- To analysis the status of girls' education at different levels.

- To carry out a region-wise analysis of girls' education to highlight the geographical variation.

- To analyze the reasons for discrepancies at various levels.

- To analyze government policies to improve girls' education.

- To put forth suggestions to bring gender equity in education.

\section{Status of Girls at Elementary Level}

Gender Parity Index (GPI) at the primary level in India was 1.15 as of 2017. Gender Parity Index for gross enrollment ratio in primary education is the ratio of girls to boys enrolled at primary level in public and private schools. It implies that all girls are enrolled at the primary level. Gross Enrolment Ratio (GER) was 100.08 in 2014-15 (U-DISE 201415, Elementary Education in India). Thus, by and large, data reveal that all girls are enrolled, and girls' education is improving. However, the case will not be the same if we consider the proportion of enrollments by gender in private and government schools. Analysis of the proportion of registration 
by gender is required in different schools by management due to the variation of cost in different school types, expenditure incurred by the family, and quality of education (perceived, not proven) associated with it. Various surveys have shown that age and grade-specific learning outcomes are poor in both state and non-state schools throughout the country. Although there is no conclusive evidence favoring private schools (Jha, J, 2015) we have a hierarchy in our schooling system.

The cost involved in private schooling leads to parental decisions in favor of boys. Return to education for girls is considered to be lower as compared to their male counterparts due to various socioeconomic factors. Girls leave their parents' house after marriage, thereby not providing them security in their old age. Households choose to provide their sons rather than daughters with an education, which is more expensive and which they perceive to be better in quality (Sahoo). The financial burden of dowry may discourage households from investing more in the girls' education; rather, they might want to save the resources for later dowry payment (Subramaniam, 1996).

Table 1: Enrolment of Girls and Boys Management Wise (2016-17)

\begin{tabular}{|c|c|c|c|c|}
\hline \multirow{2}{*}{ Class } & \multicolumn{2}{|c|}{ Government School } & \multicolumn{2}{c|}{ Private School } \\
\cline { 2 - 5 } & Girls & Boys & Girls & Boys \\
\hline $1-4$ & 50.5 & 49.5 & 44.44 & 55.53 \\
\hline $5-8$ & 51.27 & 48.73 & 44.71 & 55.29 \\
\hline $9-12$ & 50.76 & 49.24 & 44.56 & 55.44 \\
\hline
\end{tabular}

Source: U- DISE (2016-17)

Table 1 captures the gender disparity in enrollment patterns. Even among young children, the proportion of girls' enrollment in government institutions is higher while the case is reverse for boys. These differences grow larger as children get older. Private schools provide a better quality of teaching, teacher absenteeism is less, and students' learning outcomes in private schools are higher than those of government schools (Muralidharan and Kremer, 2009). However, private schools have serious equity issues; children from poorer households, lower socio-economic backgrounds, rural areas, and girls are less likely to attend private schools (Harma, 2011). Overall discrimination can be seen in terms of expenditure on education incurred by parents. Government pro-women policies in other aspects apart from education and parents' decisions should be in one line to bring desirable results. Parental education, mid-day meals, and village development affect girls' education. The Children belong to Scheduled Castes, and Scheduled Tribes (SC and ST) and Other Backward Castes (OBC) are less likely to go to school than children belonging to the general castes. Educational disadvantage is more for girls in these categories (Gandhi, G. and Dreze, J. 1999).

\section{Status of Girls at Secondary Level}

Secondary education, the second stage traditionally found in formal education, beginning about age 11 to 13 and usually ending at age 15 to 18 . Secondary education is crucial as girls with secondary education earn twice as much as those with primary education (World Bank Report, July 2018). However, girls are more likely to drop out even before reaching the secondary level. As per the educational statistics released by MHRD in 2016, there were $6,28,92,000$ girls enrolled in primary school level in the year 2014-15. The number of girls enrolled in Secondary classes was 1,81,80,000. This amounts to a difference of almost $71 \%$ (NDTV, Education).

Table 2: Number of Females Per 100 Males In Secondary And Senior Secondary Classes

\begin{tabular}{|c|c|c|}
\hline Year & $\begin{array}{c}\text { Secondary } \\
\text { Classes }\end{array}$ & $\begin{array}{c}\text { Senior Secondary } \\
\text { Classes }\end{array}$ \\
\hline $2005-06$ & 73 & 72 \\
\hline $2006-07$ & 73 & 74 \\
\hline $2007-08$ & 77 & 76 \\
\hline $2008-09$ & 79 & 77 \\
\hline $2009-10$ & 82 & 80 \\
\hline $2010-11$ & 82 & 79 \\
\hline $2011-12$ & 84 & 81 \\
\hline $2012-13$ & 89 & 87 \\
\hline $2013-14$ & 89 & 89 \\
\hline $2014-15$ & 91 & 90 \\
\hline $2015-16$ & 91 & 90 \\
\hline
\end{tabular}

Source: Men and Women in India (A statistical compilation of Gender-related Indicators in India) 2018. Central Statistics, Office MoSPI, Government of India. 
Table 2 shows the number of females per 100 males, even though the very number is constantly increasing with every passing year but remains lower than those of males. These numbers are even lower in the rural area and much lower for disadvantaged groups: Schedule Castes (SC), Schedule Tribes (ST), and Other Backward Classes (OBC).

Table 3: Net Attendance Ratio at Higher Secondary Level by Social Groups (Rural), 2007-2008 (Percent)

\begin{tabular}{|l|c|c|}
\hline \multicolumn{1}{|c|}{ Social Group } & Male & Female \\
\hline SC & 20.6 & 16.4 \\
\hline ST & 12.7 & 8.5 \\
\hline OBC & 26.4 & 19.9 \\
\hline Others & 29.4 & 24.3 \\
\hline All Social Group & 25.0 & 20.0 \\
\hline
\end{tabular}

Source: India Human Development Report 2011,

Towards Social Inclusion.

Not only numbers of females but their Net Attendance Ratio (NAR) is also lower. This implies that only a few lucky ones reach the secondary level, get admission and even fewer of them get the chance to attend classes regularly. Net Attendance Ratio is only 8.5 percent for the females belong to SC group in the year 2007-08 (Table: 3). The low attendance affects the learning outcomes and narrows down their chances to reach a higher level. Many reasons for not attending schools regularly have been cited in the related literature, such as household chores, taking care of siblings, safety issues, poor infrastructure of schools, and schools not being nearby.

\section{Status of Girls in Higher Education}

Higher education is defined as that education obtained after completing 12 years of schooling or equivalent. It is of the duration of at least nine months (full time) or after completing ten years of schooling and is of at least three years. The education may be of the nature of General, Vocational, Professional or Technical education. (AISHE).

Table 4: Level Wise Students Enrollment in Higher Education (Regular Courses) (2017-18)

\begin{tabular}{|l|c|c|c|c|}
\hline \multicolumn{1}{|c|}{ Level } & Male & Female & Total & \% of total \\
\hline Ph.D & 92750 & 68842 & 16412 & 0.50 \\
\hline M.Phill & 12287 & 21822 & 34109 & 0.10 \\
\hline Post Graduate & 1278165 & 1657638 & 2935803 & 9.00 \\
\hline Graduate & 13484766 & 12977173 & 26461939 & 81.14 \\
\hline Post Graduate Diploma & 75195 & 69989 & 145184 & 0.45 \\
\hline Diploma & 1765994 & 819196 & 2585196 & 7,93 \\
\hline Certificate & 40649 & 50972 & 91621 & 0,28 \\
\hline Integrated Courses & 114233 & 81293 & 195526 & 0.60 \\
\hline Total & 16863859 & 15746925 & 32610784 & 100.00 \\
\hline
\end{tabular}

Source: University Grant Commission, Annual Report (2017-18).

Table-4 shows the students' enrollment position in Higher Education ( Regular Courses). During the academic year (2017-18), 81.14 percent of the total students were enrolled in graduate-level courses. The percentage of students for post-graduate courses was 9.0 percent, For research courses (M.Phil/ Ph.D.) was 0.60 percent. Similarly, 8.66 percent \& 0.60 percent of students were enrolled in the PG Diploma / Diploma / Certificate and Integrated Courses. Keeping level-wise enrollment in view except for M.Phill and Post Graduate at all levels, the participation of women is less compared to their male counterparts. Diploma and Integrated courses have a major skewed distribution. According to AISHE (2015-16), Agriculture, Engineering, and Physical Education sectors have the lowest female participation.

Table 5: Percentage Distribution of Students Pursuing General and Technical/Professional Courses

\begin{tabular}{|l|c|c|}
\hline \multicolumn{1}{|c|}{ Course } & Male & Female \\
\hline Upto class X & 54.2 & 45.8 \\
\hline Humanities & 49.9 & 50.1 \\
\hline
\end{tabular}




\begin{tabular}{|l|c|c|}
\hline Science & 59.5 & 40.5 \\
\hline Commerce & 56.6 & 43.4 \\
\hline Medicine & 75.2 & 24.8 \\
\hline Engineering & 35.3 & 64.7 \\
\hline Law & 63.9 & 36.2 \\
\hline Management & 62.3 & 37.7 \\
\hline IT/ Computer Science & 61.6 & 38.9 \\
\hline $\begin{array}{l}\text { Courses from ITI / Recognised } \\
\text { Vocational Institute }\end{array}$ & 82,8 & 17.2 \\
\hline
\end{tabular}

Source: Women and Men in India-2018, 20th Issue, Chapter - 3, Central Statistics Office, National Statistical

Organization, MoSPI, Government of India.

Taking a look at the Male-Female participation in general and technical/professional courses (Table-5), it is obvious that the ratio of males is higher than females in almost every course, except for humanities. Women enrollment in auto component, warehouse, Information Technology (IT), hardware, and transportation sectors is also very less (Times of India). Women's entry into higher education and employment came via nurturing professions such as nursing and teaching. Women's participation percentage is way lower in management and Information Technology (IT).

\section{Geographical Variation}

Fig (1) illustrates the gender gap in literacy rates (2011 Census) across states. The gap is highest in Rajasthan, Madhya Pradesh, and Chattisgarh, in the central region. The discrepancy between male and female literacy rates is also higher for Jharkhand and Bihar in the eastern region. In the northern region, except for Uttar Pradesh and Jammu and Kashmir, other states are in a better position relatively. All these states above have a literacy gap either equal to or more than 20 percentage points, and the gap is even higher in the rural parts of these states.

In rural India, in 2007-8, the male literacy rate was higher than the female literacy rate for all religious communities across all states (except Himachal Pradesh in the case of Sikhs and Madhya Pradesh in the case of Christians) (India Human Development Report 2011, Towards Social Inclusion). Kerala, in the southern region and North-East region, has a low level of gender disparities, as compared to other states.

\section{Figure 1: Gender Gap in Literacy Rates}

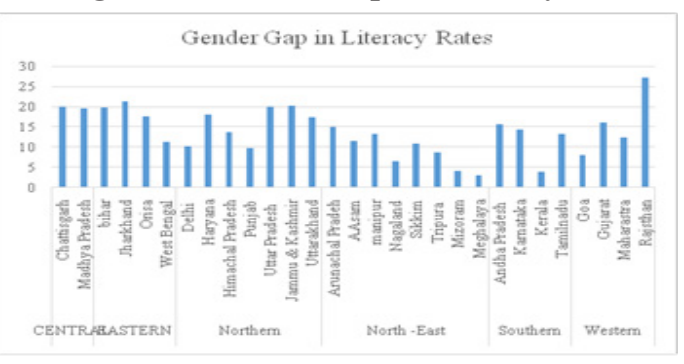

Source: Census, 2011

To comprehend the nature of disparity, other important factors should be taken into accounts, such as enrollment in government and private schools. Table (6) explains the region-wise enrolment in government and private schools. A cursory look at the table suggests that boys' enrollment is higher in private schools in all the regions. The difference between girls' and boys' enrollment in private schools is highest in the central area, followed by the western and northern parts.

Table 6: Region-Wise Enrollment in Private and Government Schools (2018)

\begin{tabular}{|l|c|c|c|c|}
\hline Region & $\begin{array}{c}\text { Private / } \\
\text { Govt. }\end{array}$ & Boys & Girls & Differences \\
\hline Central & Govt & 49.1 & 50.9 & -1.8 \\
\hline Eastern & Govt & 49.6 & 50.4 & -0.8 \\
\hline Northern & Govt & 48.5 & 51.5 & -3 \\
\hline North-East & Govt & 49 & 51 & -2 \\
\hline Southern & Govt & 48.5 & 51.5 & -3 \\
\hline Western & Govt & 50 & 50 & 0 \\
\hline central & Private & 58 & 42 & 16 \\
\hline Eastern & Private & 52.9 & 47.1 & 5.8 \\
\hline Northern & Private & 54.6 & 45.4 & 9.2 \\
\hline North-East & Private & 52.1 & 47.9 & 4.2 \\
\hline Southern & Private & 53.2 & 46.8 & 6.4 \\
\hline Western & Private & 57 & 43 & 14 \\
\hline Sourre
\end{tabular}

Source: Educational Statistics at a Glance, Ministry of Human Resource Development, 2018.

If we compare different regions, the North-East region has fared better relatively as they have the lowest gap in literacy rates.

\section{Reason for Discrepancies}

"Among the various reasons for discontinuation or dropping out, the three most important reasons 
identified in the survey (NSSO 64th Round) are lack of interest on the part of parents, lack of interest on the part of children, and financial constraints. Financial constraint was the most important factor for discontinuation/dropping out for all other social groups and religious communities." (India Human Development Report 2011, Towards Social Inclusion)

The parent's decision happens to be based on either the family's income or social or cultural norms. These stereotypes are a big barrier for girl child education.

There could be other reasons, such as underdeveloped schools, unqualified teachers, and safety issues that make children reluctant to attend school.

Financial Constraint is one of the main ideas for discrimination against women. Parents want to allocate their limited resources to educate their sons as they believe they will get more return on the investment.

\section{Different Interventions by Policymakers}

Since independence in 1947, the Indian Government initiated various programs to address the problems of illiteracy in both rural and urban parts. India adopted a federal structure of governance in which responsibilities are distributed between centers and states.

The Government of India appointed an Education Commission in 1964 under the Chairmanship of Dr. D.S. Kothari. One of the main recommendations of the Kothari commission was the standardization of the educational system on $10+2+3$ pattern across the country. It also emphasized free education up to fourteen years of age and included the lower secondary education level. Commission laid stress on women's education and advised setting up state and central level committees for overseeing women's education. It suggested establishing schools and hostels for women and urged them to find job opportunities for women in the educational sector.

Prime Minister Rajiv Gandhi's National Policy on Education in May 1986 emphasized removing disparities and equalizing educational opportunities, especially for women, Scheduled Tribes (ST), and the Scheduled Caste (SC) communities. A committee was set up under the chairmanship of Acharaya Rammurti in May 1990 to review the recommendations of the National Policy of Education (NPE) and to make recommendations for its modifications.

District Primary Education Programme (DPEP) in 1994 was launched to achieve the objective of universal primary education. The impact of DPEP on minority children was impressive, while there was little evidence of any impact on the enrollment of girls.

Sarva Shiksha Abhiyān (Education for All Movement, SSA) was an ambitious Government of India initiative which aimed at the universalization of elementary education in a time-bound manner. Within the ambit of SSA, a special thrust was also brought on girls' education through the National Programme of Education for Girls at Elementary Level (NPEGEL, launched in 2003) and Kasturba Gandhi Balika Vidyalaya (KGBV, launched in 2005). These programs aimed to provide access to elementary education for girls through community mobilization and cluster development.

The government of India passed the Right of Children to Free and Compulsory Education (RTE) Act 2009. The Right to Education Act (RTE) came into force on 1 April 2010. As per RTE Act norms, all private schools must enroll children from weaker sections and disadvantaged communities. The private schools have to do these enrollments in their incoming class to the extent of $25 \%$ of their enrollment.

Following are a few government policies in India that are meant to promote women in higher education. Few policies that are especially for the higher technical education of women:

- Post Graduate Indira Gandhi Scholarship Scheme for Single Girl Child Swami Vivekanand Single Girl Child Scholarship for Research in Social Sciences to encourage women participation in higher education.

- UDAAN is an initiative of the Central Board of Secondary Education (CBSE) to enable disadvantaged girl students and other students from $\mathrm{SC} / \mathrm{ST}$ and minorities to transit from school to post-school professional education, especially 
in science and maths, through free and online resources.

- PRAGATI (Providing Assistance for Girls' Advancement in Technical Education Initiative) is an AICTE scheme that envisages selecting one girl per family (where family income is less than six lakhs per annum) on merit at the qualifying examination to pursue technical education.

\section{Community-Level Initiative to Help Street Children}

Many states initiated various community-level programs to help working children. MV Foundation at Shankarpalle Mandal, Ranga Reddy district, in Andhra Pradesh, involves the community to ensure that every child stays in school and completes the elementary level. Baljyoti program in Hyderabad mobilized the community, created an environment and infrastructure to enable all children to access schools. Child in Need Institution (CINI) in Kolkata works on the same principles, focusing on street children, those living on the railway platform, and children of sex workers. Namma Bhoomi experiment of Concerned for Working Children (CWC) Karnataka and Centre for Rural Education and Development Action (CREDA) Mirzapur, Uttar Pradesh work educate working children by involving community and administration for making schools child-sensitive and supportive.

\section{Suggestions}

Following points can be suggested to improve women' participation in education:

- Providing safety by enforcement of strict law and order, setting up the schools and colleges nearby, and providing hostels can go a long way to bring equality.

- Government policies can't be translated completely unless social and cultural norms facilitate the environment to implement them at ground level. To change the perception of people for girl child education, community-level efforts should be made. There should be strict laws against dowry and early marriage, which are the major cause of girls' illiteracy, especially amongst Schedule Caste and Schedule Tribes (SC \& ST).
- Financial help, scholarships, and stipends can alleviate the family financial burden and remove the hurdles of women's education.

- Usually, women leave education at the secondary level. Proper counseling should be given to the family so that they can understand the importance of education.

\section{Conclusion}

To conclude, gender discrimination in terms of access to education is prevalent. The form of discrimination is also evolving with the demand for quality and equitable education. At the elementary level, girls are not being sent to expensive institutions. Girls are likely to drop out more at the secondary level, and at a higher level, girls' enrollment is very less in engineering, law, management, and institutes of national importance. Discrimination at different levels of education varied across states. Some states are in a better position regarding gender equity and literacy rates, such as North-East and Kerala in the South. The government has launched several policies, and efforts have been made at the community level. Despite that, discrimination has been there in one form or the other.

Along with government policies, few structural changes are needed in the cultural, social, and educational domains to address this problem. Changing social and cultural norms are crucial to change the mind-set of the people. Another important aspect is the hierarchy in the education system. We need to move towards a common schooling system to ensure all will get the same education irrespective of their economic class, caste, and gender.

\section{References}

All India Survey of Higher Education, http://aishe. nic.in/aishe/home

Borghans, Lex, et al. "School Quality and the Development of Cognitive Skills between Age Four and Six." PloS one, vol. 10, no. 7, 2015.

Bose, Sunita. "A Contextual Analysis of Gender Disparity in Education in India: The Relative Effects of Son Preference, Women's Status, and Community." Sociological Perspectives, vol. 55, no. 1, 2012, pp. 67-91. 
Chaudhary, Kausik. and Susmita Roy. "Do Parents Spread Educational Expenditure Evenly across the Two Genders? Evidence from Two North Indian States." Economic and Political Weekly, vol. 41, no. 51, 2006.

De, Anuradha, et al. "Private Schools for Less Privileged: Some Insights from a Case Study." Economic and Political Weekly, vol. 37, no. 52, 2003.

Dreze, Jean and Geeta Gandhi Kingdon. "School Participation in Rural India." DEDPS No. 18, 1999

Govinda, R., and Madhumita Bandyopadhyay. Access to Elementary Education in India: Country Analytical Review, CREATE, 2008.

Harma, Joanna. "Access or Quality? Why do Families Living in Slums Choose Low-Cost Private Schools in Lagos, Nigeria?." Oxford Review of Education, vol. 39, no. 4, 2013, pp. 548-566.

Hussain, Zakir. "Gender Disparities in Completing School Education in India: Explaining Geographical Variations." Journal of Population Research, vol. 28, no. 4, 2011.

"India - School Enrollment, Primary (gross), Gender Parity Index (GPI)." Index Mundi, https:// www.indexmundi.com/facts/india/indicator/ SE.ENR.PRIM.FM.ZS

India Human Development Report 2011: Towards Social Inclusion, Institute of Applied Manpower Research. Planning Commission, Government of India.

Johnson, Adlyn O. "The Participation of the Female Sex in Technical Education: A Case Study of the Eastern Polytechnic, Kenema." International Journal of Educational Research and Technology, vol. 4, no. 3, 2013, pp. 117-121.

Kambhapati, Uma S. "Does Household Expenditure in India Depend upon Return to Education?" CIP Working Paper No. 2008-060, 2008.
Kesarwani, Deepti, and Jadi Bala Komaraiah. "Determinants of Women's Enrolment in Higher Technical Education in India: A Review." Edu-Tech, 2019.

Mishra, Shivangi. "Women enrolment in Unconventional Technical Courses is on a Rise." The Times of India, 2018,

Mohanty, Itismita. Gender Discrimination in Child Schooling: Why do We Observe the Gender Disparity?. 2006.

Muralidharan, Karthik, and Michael Kremer. "Public-Private Schools in Rural India." School Choice International: Exploring Public-Private Partnerships. MIT Press, 2008.

Parmar, D.K., and V.K. Modi. "Women in Higher and Technical Education in India." International Journal of Combined Research \& Development, vol. 5, 2016, pp. 1683-1690.

Ramandran,Vimala. "Backward and Forward linkages that Strengthen Primary Education." Economic and Political Weekly, vol. 38, no. 10, 2003, pp. 958-968.

Sahoo, Soham. "Intra-Household Gender Disparity in School Choice: Evidence from Private Schooling in India." The Journal of Development Studies, vol. 53, no. 10, 2017, pp. 1714-1730.

"Secondary Education." Britannica, https://www. britannica.com/topic/secondary-education

Singh, Anisha. "Why Girls Drop Out Before Secondary School In India?." NDTV Education, 2018.

Tilak, Jandhyala B. G. "How Free Is 'Free' Primary Education in India?." Economic and Political Weekly, vol. 31, no. 5, 1996.

Tilak, Jandhyala B.G. "Inequality in Education by Sex in India." Indian Journal of Industrial Relations, vol. 18, no. 3, 1983, pp. 375-395.

\footnotetext{
Author Details

Deepmala Yadav, Research Scholar, Bangalore University, Bengaluru, Karnataka, India, Email ID: deepay2019@gmail.com
}

Suma Singh, Associate Professor, Mount Carmel College, Bengaluru, Karnataka, India. 